\title{
Biosolid Soil Application: Toxicity Tests under Laboratory Conditions
}

\author{
Cintya Ap. Christofoletti, Annelise Francisco, and Carmem S. Fontanetti
}

São Paulo State University (UNESP), Avenue 24-A, No. 1515, CP 199, 13506-900 Rio Claro, SP, Brazil

Correspondence should be addressed to Carmem S. Fontanetti, fontanet@rc.unesp.br

Received 5 January 2012; Revised 5 April 2012; Accepted 26 April 2012

Academic Editor: Leonid Perelomov

Copyright (C 2012 Cintya Ap. Christofoletti et al. This is an open access article distributed under the Creative Commons Attribution License, which permits unrestricted use, distribution, and reproduction in any medium, provided the original work is properly cited.

\begin{abstract}
A large volume of generated sewage sludge makes its disposal a problem. The usage of sludge in agriculture is highlighted by a number of advantages. However, heavy metals and other toxic compounds may exercise harmful effects to soil organisms. This study evaluated the possible toxic effects of a biosolid sample, under laboratory conditions, for 30 days, using diplopods Rhinocricus padbergi and plants Allium cepa (onion) as test organisms. The data obtained demonstrated that the biosolid raw sample had genotoxic potential for Allium cepa root tip cells. In the diplopods exposed to biosolid sample, epithelium disorganization in the midgut and a reduction of the volume of the hepatic cells were observed after 7 days of exposure. After 30 days, the animals still showed a reduction of the volume of the hepatic cells, but in minor intensity. Allium cepa analysis showed genotoxicity, but this effect was reduced after 30 days of bioprocessing by diplopods. This study was important to know the effects as well as to determine how this waste could be applied concerning the soil living organisms and plants.
\end{abstract}

\section{Introduction}

In sewage treatment plants (STP), after the sewage had been treated, a sludge rich in organic matter and nutrients is generated as a waste, known as sewage sludge. The composition of this sludge is very variable since it depends on the source of the sewage treatment process and the seasonality [1]. Generally, the sewage sludge presents around $40 \%$ to $60 \%$ of organic matter, $4 \%$ nitrogen, $2 \%$ phosphorus, and other macro- and micronutrients, besides potentially toxic elements [2].

The generated sewage sludge still can go through processes in order to increase the solids and reduce the number of pathogenic organisms, generating a residue called biosolid, which is considered most innocuous than the sewage sludge itself [3]. Good quality fertilizers can be generated with the sludge stabilization, reducing its volume through the use of "sludge thickeners drying beds," filter presses, band presser, vacuum filters, and centrifugation [4]. According to Lambais and Do Carmo [5], chemical composition of the sludge depends on the origin of the wastewater. This way, the material is variable, but generally it is a compound rich in organic matter and essential nutrients for plants and microorganisms.

Currently, sewage treatment plants in different Brazilian cities are facing the problem of sludge disposal. The alternatives to the sewage sludge usual fate are landfill disposal, reuse in industry (light-weight aggregate production, bricks and ceramics manufacturing, and cement production), incineration, conversion into fuel oil, ocean disposal, recovery degraded soils, and agricultural use $[2,6]$.

In Brazil, there is a preference for the use of sludge in agriculture, since there is a considerable land availability and the costs would be relatively low. However, this practice is still incipient, so that the application is made without an adequate management [4]. According to Melo et al. [7], when incorporated into the soil, sewage sludge provides changes in physical properties such as density, aggregates size, and water retention capacity; on chemical properties such as $\mathrm{pH}$, electrical conductivity, CEC, and increased levels of $\mathrm{P}$ and $\mathrm{N}$ and biological properties, usually by increasing soil microbial activity.

However, the main limitation observed during the evaluation of possible utilization of sewage sludge in agriculture 
refers to the presence of metals and other persistent pollutants [8], which may be toxic to plants [9], microorganisms [10], and soil invertebrates [11]. Although other work related the phytoavailability of these metals to a variety of cultures, few studies relate the sewage sludge to genotoxic and mutagenic potential. The application of metal-rich biosolids in clay and sandy soils, compared with biosolids with low-metal concentration, causes a transient soil microbial community increase in mass and activity, with reduced carbon immobilization [5]. Many field studies, based on biosolids agronomic doses, reported soil biota stimulation, probably due to the addition of organic matter, which causes an increase in fertility. The application of this kind of compound, however, has shown inhibitory effect on soil invertebrates [12].

Thus, the aim of this study was to investigate the effects of a biosolid sample according to Brazilian standards for its application on soils, under laboratory conditions, using Allium cepa (plant) and Rhinocricus padbergi (terrestrial invertebrate) as test organisms.

\section{Materials and Methods}

2.1. Rhinocricus padbergi. Adult specimens of R. padbergi with a mean size of $5.0 \mathrm{~cm}$ were collected at the campus of the São Paulo State University (UNESP), Rio Claro, in order to avoid intraspecific differences related to either diplopod size or age. After collection, the specimens were maintained in the laboratory for 3 weeks for acclimation, in a terrarium containing soil, tubercles, and decomposing pieces of tree trunks from the capture area. The experimental temperature was $21 \pm 2^{\circ} \mathrm{C}$ and the photoperiod was a $12: 12$-h light/dark cycle.

2.2. Allium cepa. All assays were carried out with only one kind of seeds of $A$. cepa (variety Baia Piriforme) to avoid different responses in the several stages of the process.

2.3. Control Soil. The control soil was obtained from the site where diplopods were collected at a depth of $0-20 \mathrm{~cm}$, in the UNESP Campus of Rio Claro, SP. Soil samples were homogenized, dried at room temperature, and sieved with $4 \mathrm{~mm}$ mesh.

2.4. Biosolid Sample. The wastewater treatment plant where the biosolid was collected occupies an area of 20 hectares. The facility serves approximately $80 \%$ of the 318.785 inhabitants [13] of a city in São Paulo state where sewage is treated by conventional activated sludge process. In October 1999, the plant received the license of Producer of Agricultural Amendments, by the Ministry of Agriculture. The product produced in the facility is a biosolid classified as soil conditioner. The brand name is Sabesfértil (SP-09599 00001-0). Biosolid samples were collected and stored in plastic boxes wrapped with dark plastic bags and maintained in a cold room $\left(4^{\circ} \mathrm{C}\right)$, until use.

2.5. Chemical Analysis of Samples. The concentration of trace elements (As, Ba, Cd, Cu, Cr, Hg, Mo, Ni, Pb, Se, and $\mathrm{Zn}$ ) and the 16 priority organic compounds (PAHs) in the biosolid and control soil was determined followed the Standard Methods for the Examination of Water and Wastewater 21th Edition 2005 (SM21) and USEPA. The characterization of samples was measured by TASQA Laboratory (Paulínia, São Paulo, Brazil). Analyses of trace elements were performed by inductively coupled plasma emission spectrometry (ICPAES). The PAHs analyses were performed by atomic absorption spectrometry. Chemical and physicochemical analyses, as well as a characterization of control soil sample based on macro- and micronutrients (N, Ca, Mg, P, K, S, Fe, Mn, $\mathrm{Cu}$, and $\mathrm{Zn}), \mathrm{C} / \mathrm{N}$ ratio, organic matter, cation exchange capacity (CEC), and base-saturation percentage, were carried out by the Instituto Campineiro de Análise de Solo e Adubo (ICASA), Campinas, São Paulo, Brazil.

\subsection{Calculating Biosolid Quantities for Application}

2.6.1. Application of Sewage Sludge. According to the law 375/2006 of the Environmental National Council (Conselho Nacional do Meio Ambiente, CONAMA) [14], the maximum annual application of sewage sludge and derivatives in tons per hectare shall not exceed the quotient between the quantity of nitrogen recommended for the crop (in $\mathrm{kg} / \mathrm{ha}$ ), following the official recommendation for São Paulo State and the nitrogen content available in the sewage sludge or derivatives (in $\mathrm{kg} / \mathrm{t}$ ), calculated as $\mathrm{N}$ recommended $(\mathrm{kg} / \mathrm{ha}) / \mathrm{N}$ available $(\mathrm{kg} / \mathrm{t})$.

To determine the nitrogen available in the sewage sludge and/or biosolid, mineralization fractions were calculated. According to CONAMA [14], this fraction represents $40 \%$ of undigested and $20 \%$ of digested sewage sludge.

2.6.2. Preparation of Soil and Residue Sample for the Bioassays with $R$. padbergi. Two glass terraria with capacity for $22.5 \mathrm{~L}$ were filled with $5 \mathrm{Kg}$ of control soil each. After physicochemical analysis of soil samples and biosolid, the following bioassays were set up with control soil (CS) and soil + biosolid (SB):

(1) CS: $5 \mathrm{Kg}$ of control soil;

(2) SB: $5 \mathrm{Kg}$ of control soil $+234.4 \mathrm{~g}$ of biosolid.

Twenty specimens of $R$. padbergi were then placed in each terrarium, where they remained for 30 days to assess the toxicity of contaminants present in biosolid. The animals were monitored for 90 days. Six animals per bioassay were dissected for histological analyses, three animals on the seventh day, and three diplopods in 30th day of exposure.

2.6.3. Histology of the Midgut. The diplopods were anesthetized with chloroform, placed in Petri dishes containing isotonic salt solution, and dissected under the dissecting scope. The midgut was removed and fixed in paraformaldehyde $4 \%$. Following that, the organ was dehydrated in increasing concentrations of ethanol $(70 \%, 80 \%, 90 \%$, and $95 \%$ ), embedded in resin (Leica historesin), and kept in the refrigerator for $24 \mathrm{~h}$. Later, the material was transferred to plastic moulds containing inclusion resin. After polymerization, $6 \mu \mathrm{m}$ slices were obtained with the help of a Leica 
RM2245 microtome. For histological analyses, sections were stained with hematoxylin and eosin.

2.7. Germination of A. cepa Seeds in Residue Samples at Time $0\left(t_{0}\right)$ and after Exposure to Diplopods after 30 Days $\left(t_{30}\right)$. Approximately 100 seeds of $A$. cepa were allowed to germinate at $22^{\circ} \mathrm{C}$ in Petri dishes containing raw biosolid sample (B) and soil from each terrarium: CS and SB samples were collected and placed in Petri dishes for the germination of $A$. cepa seeds, at time $0\left(t_{0}\right)$. Positive controls were made with the aneugenic herbicide trifluralin (TRIF) at the concentration of $0.019 \mathrm{ppm}$ [15] and methyl methanesulfonate (MMS), a clastogenic agent at the concentration of $10 \mathrm{mg} / \mathrm{mL}$ [16]. Negative control (NC) consisted of seeds allowed to germinate in ultrapure water and the environmental control (CS) consisted of seeds allowed to germinate in the control soil.

After 30 days of exposure by diplopods, soil samples from each terrarium were collected for the tests with onion seeds.

2.7.1. Preparation of Slides of A. cepa. After germinating and reaching $2 \mathrm{~cm}$ in length, root tips were collected and fixed with Carnoy ( $3: 1$ ethanol/acetic acid). Samples were then stained with the Feulgen reaction [17], with acid hydrolysis for 11 minutes. Root tips were sectioned to remove the meristem and region $\mathrm{F}_{1}$. To intensify the staining and spread cells, one drop of $2 \%$ acetic carmine was added. All samples were lightly pressed between slide and coverslip. Coverslips were removed with liquid nitrogen and slides were mounted with Enthelan. The material was analyzed under light microscope, at magnification of 400x.

2.7.2. Evaluation of the Cytotoxic, Genotoxic, and Mutagenic Effects on Meristematic Cells of A. cepa. A total of 5000 cells were examined for each treatment at $t_{0}$ and $t_{30}$ and for the negative and positive controls. Cytotoxicity was assessed based on morphological alterations indicating cell death, and the mitotic index $(\mathrm{MI})$ calculated as $\mathrm{MI}=$ (number of dividing cells/total number of observed cells $) \times 100$. The cells in death process present a vacuolated cytoplasm, which is outcome of the cytoplasmatic organelles digestion by lysosomal enzymes [18]. They can still present enhanced cytoplasmatic volume, which can lead to a rupture of the plasmatic membrane exposing the cell content to the outer media [19].

Genotoxicity was evaluated based on the number of cells with chromosome aberration (CA). For the CA analyses, several aberrations within different cell divisions (metaphase, anaphase, and telophase) were considered such as Cmetaphase, chromosomal adherence, multipolar anaphase and telophase, and chromosome bridge and loss [20]. The frequency of CA was calculated as CAI $=$ (number of cells with chromosome aberrations/total number of observed cells $) \times 100$. Mutagenicity index $(\mathrm{IMt})$ was determined based on the occurrence of cells with micronuclei (MN) and chromosome breaks, calculated as IMt $=$ (total number of cells with $\mathrm{MN}$ and breaks/total number of observed cells $) \times 100$. The results obtained in all treatments at the different periods were compared with the negative control and soil control at their corresponding times with the Mann-Whitney test, with significance set at 0.05 .

2.7.3. Evaluation of Micronuclei in Cells of the $F_{1}$ Region of A. cepa. The damage to meristematic cells was assessed based on the number of micronuclei in cells of the $\mathrm{F}_{1}$ region, which is composed by differentiated cells and is located about $1 \mathrm{~mm}$ above the meristematic region [21]. A total of 5000 cells were examined per treatment. The results obtained for all samples were compared with the negative control and soil control at their corresponding times with the Mann-Whitney test, with significance set at 0.05 .

\section{Results}

3.1. Chemical Characterization of Samples. To follow a Brazilian standard for application of biosolids on soil, data regarding the agronomic potential and fertility of control soil became necessary. The values obtained are presented in Table 1. The results obtained by physical-chemical and trace elements analysis of control soil and biosolid sample are presented in Table 2. The concentrations of arsenic and copper found in the control soil were above the limits determined by CETESB-195/2005-E [22], but below the limits for intervention in agricultural areas. Levels of barium, lead, copper, chromium, molybdenum, nickel, and zinc found in the biosolid were high, but below the maximum level allowed by CONAMA (Table 2). None of the 16 PAHs, priority by EPA, were detected by analyses.

3.2. Histology of the Midgut of Diplopods. Animals from control soil presented the midgut (Figure 1(a)) as the histological pattern described for the species [23], being, therefore constituted by a pseudostratified epithelium with brush border (arrow head in Figure 1(a)). The epithelium showed principal cells with nuclei of round to oval morphology, located in middle apical region and regenerative cells in the basal portion; the epithelium is followed by a muscular layer and hepatic cells layer covered by an external membrane. The hepatic cells had an irregular morphology, spherical nucleus, and cytoplasm with cytoplasmic granules of varied content. Among the hepatic cells, some hemocytes were observed, generally isolated.

The group exposed for one week to SB showed epithelium disorganization (arrow in Figure 1(b)) with disruption in several places, indicating an epithelium renewal. The hepatic cells layer showed disorganization with volume reduction in some cells (Figure 1(c)).

After 30th day of exposure, animals from SB sample showed the minor disorganization of the hepatic cells layer when compared to the midgut of the animals exposed for 7 days (Figure 1(d)).

3.3. Cytotoxic, Genotoxic, and Mutagenic Effects on A. cepa. The mitotic index of cells examined for B, SB, TRIF, MMS, $\mathrm{CS}$, and $\mathrm{NC}$ at 0 and after 30 days of exposure to diplopods is presented in Table 3. Seeds exposed to B and SB samples presented the highest mitotic index in both periods of exposure. However, no sample was statistically significant 
TABLE 1: Fertility parameters of the control soil.

\begin{tabular}{lcccccccccccc}
\hline \multirow{2}{*}{ Sample } & $\mathrm{pH}$ & $\mathrm{g} / \mathrm{dm}^{3}$ & $\mathrm{mg} / \mathrm{dm}^{3}$ & \multicolumn{3}{c}{$\mathrm{mmol} / \mathrm{dm}^{3} \mathrm{TFSA}$} & \multicolumn{3}{c}{$\%$} & \multicolumn{2}{c}{$\mathrm{Ratio}$} \\
& $\mathrm{CaCl}_{2}$ & $\mathrm{OM}$ & $\mathrm{P}$ res & $\mathrm{K}$ & $\mathrm{Ca}$ & $\mathrm{Mg}$ & $\mathrm{H}+\mathrm{Al}$ & $\mathrm{SB}$ & $\mathrm{CEC}$ & $\mathrm{V}$ & $\mathrm{Ca} / \mathrm{Mg}$ & $\mathrm{Mg} / \mathrm{K}$ \\
\hline Soil & 6.20 & 18 & 3.0 & 0.8 & 2 & 1 & 88 & 3.9 & 91.9 & 4.2 & 2.0 & 1.25 \\
\hline
\end{tabular}

OM: organic matter; CEC: cation-exchange capacity; V: base saturation.

TABle 2: Physicochemical and metal analysis of the control soil and biosolid sample.

\begin{tabular}{|c|c|c|c|c|c|}
\hline \multirow{2}{*}{ Parameter } & \multicolumn{2}{|c|}{ Samples } & \multirow{2}{*}{ Method } & \multirow{2}{*}{$\mathrm{G}(\mathrm{mg} / \mathrm{kg})$} & \multirow{2}{*}{$\mathrm{MCA}(\mathrm{mg} / \mathrm{kg})$} \\
\hline & $\mathrm{CS}(\mathrm{mg} / \mathrm{kg})$ & $\mathrm{B}(\mathrm{mg} / \mathrm{kg})$ & & & \\
\hline Arsenic & 16.8 & $<\mathrm{LQ}$ & SM21 3120B & 3.5 & 41 \\
\hline Barium & 5.91 & 158 & SM21 3120B & 75 & 1300 \\
\hline Cadmium & $<\mathrm{LQ}$ & $<\mathrm{LQ}$ & SM21 3120B & $<0.5$ & 39 \\
\hline Total calcium & 25.4 & 3939 & SM21 3120B & - & - \\
\hline Organic carbon (g/kg) & 12.6 & 279 & SSSA Cap40 & - & - \\
\hline Lead & 49.3 & 174 & SM21 3120B & 17 & 300 \\
\hline Copper & 37.2 & 276 & SM21 3120B & 35 & 1500 \\
\hline Electric conductivity $(\mu \mathrm{s} / \mathrm{cm})$ & 115 & 5389 & SM21 3120B & - & - \\
\hline Chromium & 31.2 & 224 & SM21 3120B & 40 & 1000 \\
\hline Total sulfur & 151 & 11864 & SM21 3120B & - & - \\
\hline Total phosphorus & 182 & 17027 & SM21 3120B & - & - \\
\hline Total magnesium & $<\mathrm{LQ}$ & 358 & SM21 3120B & - & - \\
\hline Mercury & $<\mathrm{LQ}$ & 1.08 & EPA 7470A & 0.05 & 17 \\
\hline Molybdenum & 3.64 & 9.55 & SM21 3120B & $<4$ & 50 \\
\hline Nickel & 13.0 & 82.3 & SM21 3120B & 13 & 420 \\
\hline Nitrate $(\mathrm{mg} / \mathrm{Kg})$ & 4.40 & 6.79 & $\mathrm{SM} 214500-\mathrm{NO}^{-3} \mathrm{E}$ & - & - \\
\hline Nitrite $(\mathrm{mg} / \mathrm{Kg})$ & 0.06 & 1.39 & $\mathrm{SM} 214500-\mathrm{NO}^{-2} \mathrm{~B}$ & - & - \\
\hline Ammoniacal nitrogen $(\mathrm{mg} / \mathrm{kg})$ & 31.8 & 167 & $\mathrm{SM} 214500-\mathrm{NH}_{3} \mathrm{E}$ & - & - \\
\hline Kjeldahl nitrogen (mg/Kg) & 476 & 21620 & SM21 4500-Norg B & - & - \\
\hline $\mathrm{pH}$ & 6.20 & 8.01 & EPA 4095 C & - & - \\
\hline Total potassium & 406 & 2152 & SM21 3120B & - & - \\
\hline Selenium & $<\mathrm{LQ}$ & $<\mathrm{LQ}$ & SM21 3120B & 0.25 & 100 \\
\hline Total sodium & $<\mathrm{LQ}$ & $<\mathrm{LQ}$ & SM21 3120B & - & - \\
\hline Solid content & 0.86 & 0.24 & SM21 2540B & - & - \\
\hline Moisture (g/g) & 0.14 & 0.76 & SM21 2540B & - & - \\
\hline Zinc & 23.2 & 825 & SM21 3120B & 60 & 2800 \\
\hline
\end{tabular}

CS: control soil; B: biosolid; LQ: limits of quantification; IV: inconsistent value; G: guidelines of quality for soil (mg/kg) and groundwater in São Paulo State, according to CETESB (195/2005-E); MCA: maximum concentration allowed in sewage sludge or derivative product, according to CONAMA (375/2006).

TABle 3: Mean and standard deviation of the mitotic (MI), the chromosome aberration (CA), and mutagenicity indexes (IMt) in meristematic cells of Allium cepa after exposure to control soil, negative and positive controls, and biosolid samples.

\begin{tabular}{|c|c|c|c|c|c|c|c|}
\hline \multicolumn{2}{|c|}{ Samples } & \multicolumn{2}{|c|}{ MI } & \multicolumn{2}{|c|}{ ICA } & \multicolumn{2}{|c|}{ IMt } \\
\hline & & $t_{0}$ & $t_{30}$ & $t_{0}$ & $t_{30}$ & $t_{0}$ & $t_{30}$ \\
\hline \multirow{4}{*}{ Controls } & $\mathrm{NC}$ & $13.66 \pm 1.37$ & $11.2 \pm 1.78$ & $1.2 \pm 0.83$ & $2 \pm 1$ & $0.2 \pm 0.44$ & $0.6 \pm 0.54$ \\
\hline & CS & $14.21 \pm 0.90$ & $9.48 \pm 1.07^{2}$ & $2 \pm 0.70$ & $1.6 \pm 1.14$ & $0.6 \pm 0.54$ & 0 \\
\hline & MMS & $11.53 \pm 0.88$ & $5.73 \pm 1.15$ & $8.6 \pm 3.04^{* 1}$ & $14.2 \pm 2.94^{* 1}$ & $25.6 \pm 8.5^{* 1}$ & $24.8 \pm 7.29^{* 1}$ \\
\hline & TRIF & $9.47 \pm 0.54$ & $9.31 \pm 1.35$ & $51.4 \pm 8.79^{* 1}$ & $23.6 \pm 4.82^{* 1}$ & $12.2 \pm 3.42^{* 1}$ & $3.6 \pm 0.89 * 1$ \\
\hline Raw & B & $15.36 \pm 0.99$ & NA & $2.15 \pm 1.12$ & NA & $0.16 \pm 0.18$ & NA \\
\hline Combination & SB & $15.07 \pm 0.56$ & $15.03 \pm 0.79$ & $21 \pm 5.83^{* 1}$ & $10.6 \pm 3.33^{* 1,2}$ & $1.2 \pm 1.3$ & $0.4 \pm 0.54$ \\
\hline
\end{tabular}

NC: negative control; CS: control soil; MMS: positive control; TRIF: positive control; B: raw biosolid sample; SB: soil + biosolid.

$t_{0}$ : time of mixing and $t_{30}$ : after 30 days of exposure to the diplopods.

* Statistically significant values when compared to the negative control, by Mann-Whitney test, $P<0.05$.

${ }^{1}$ Statistically significant values when compared to the control soil, by Mann-Whitney test, $P<0.01$.

${ }^{2}$ Statistically significant values when compared to the same treatments at 0 and 30 days.

NA: not available. 

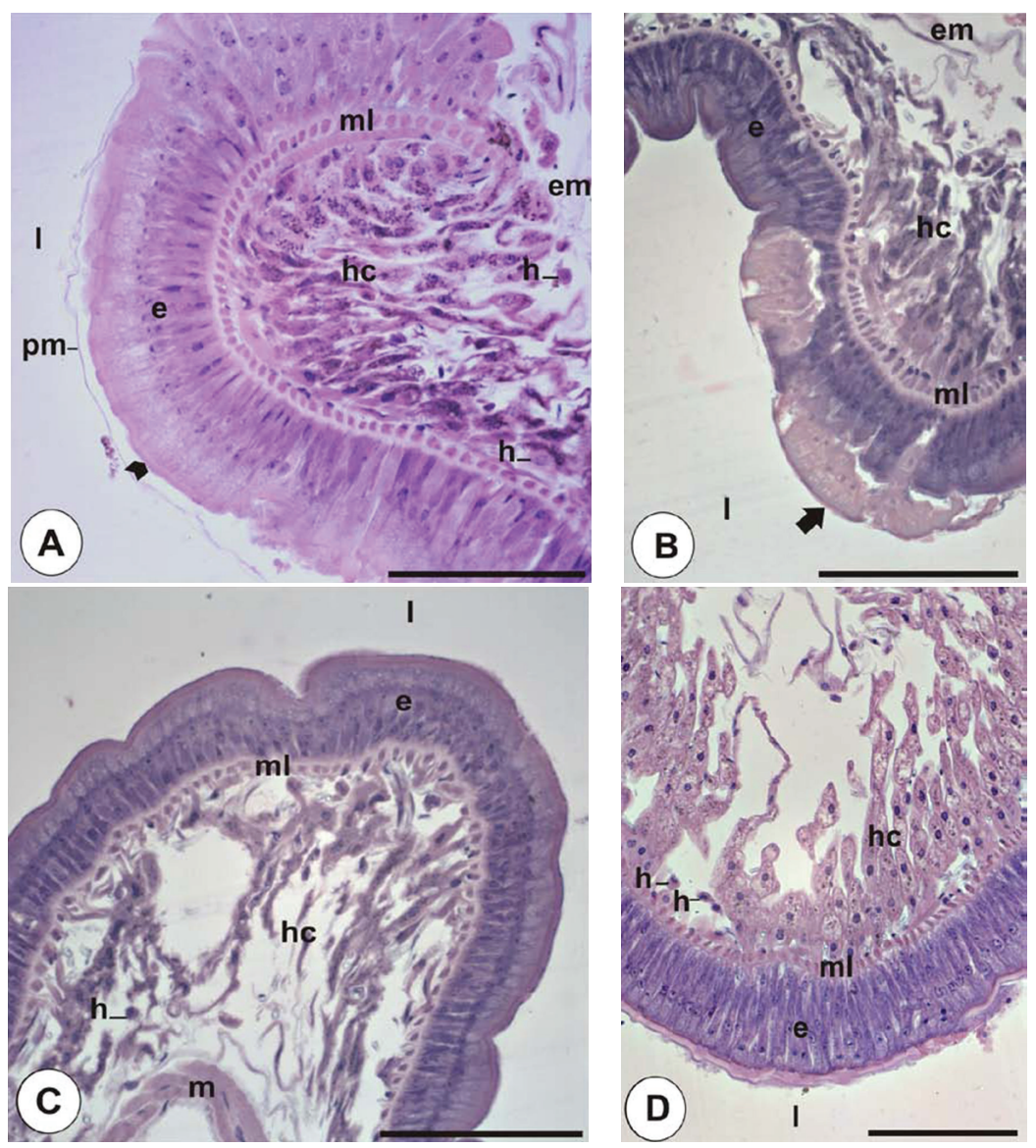

FIgURE 1: Micrographs of the R. padbergi midgut stained with HE. (A) Animals exposed for 7 days to the control soil; (B, C) animals exposed for 7 days to soil + biosolid; (D) animals exposed for 30 days to soil + biosolid. e: epithelium; em: external membrane; h: hemocyte; hc: hepatic cells; l: lumen; m: muscle fibers; ml: muscular layer; pm: peritrophic membrane; arrow head in (A) brush border; arrow in (B) epithelium renewal. Scale bars $=100 \mu \mathrm{m}$.
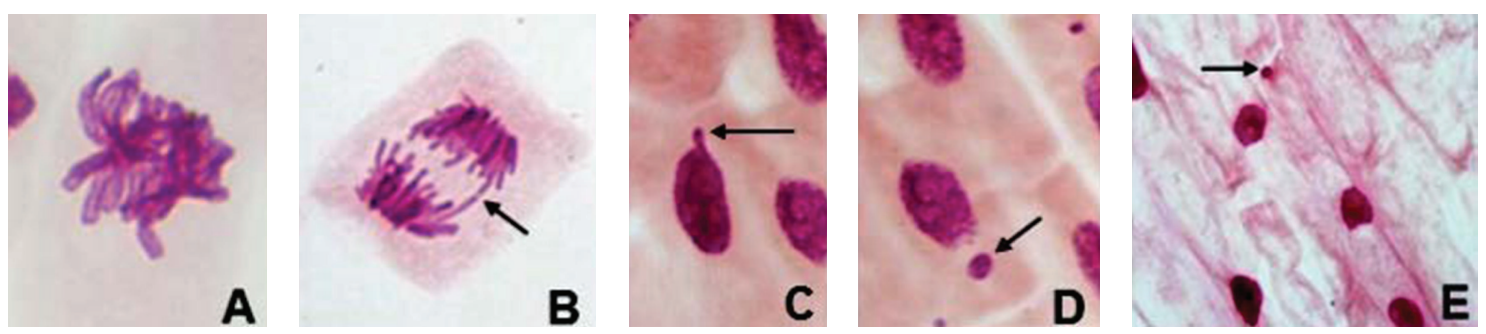

Figure 2: Chromosomal aberrations in Allium cepa exposed to raw biosolid (B) and control soil + biosolid (SB); (A) chromosomal adherence; (B) anaphase with polyploidy and chromosome bridge (arrow); (C) nuclear bud (arrow); (D) meristematic cell carrying micronuclei (arrow); (E) micronuclei in cells of the $\mathrm{F}_{1}$ region (arrow).

when compared to the negative control. In comparison to the values obtained between the CS and B samples there was a significant difference. There were no cells in the cell death process for all samples.

$\mathrm{B}$ and SB samples induced genotoxic effects (Table 3), at $t_{0}$ and $t_{30}(P<0.05)$, characterized by chromosome aberrations, compared to the negative control and/or control soil. However, the genotoxic effect was significantly reduced after the bioprocessing by diplopods in the SB group. The most frequently observed alterations in the present study were cells in metaphase with chromosomal adherence (Figure 2(a)), polyploidy (Figure 2(b)), anaphase with chromosomal bridge (Figure 2(b)), and nuclear bud (Figure 2(c)).

Meristematic cells with micronuclei (Figure 2(d)) and chromosome breaks were examined to assess the mutagenicity. Statistical analysis revealed no mutagenic effect of the samples examined at both times of exposure compared to the negative control and/or control soil (Table 3). Although micronuclei has been observed in meristematic and $\mathrm{F}_{1}$ region (Figure 2(e)), the values were not statistically significant 
TABLE 4: Mean and standard deviation for micronuclei in cells of the meristematic region (M) and $\mathrm{F}_{1}$ of Allium cepa after exposure to control soil, negative and positive controls, and biosolid samples.

\begin{tabular}{lccccc}
\hline \multicolumn{1}{c}{ Samples } & & & $t_{0}$ & & $t_{30}$ \\
& & $\mathrm{M}$ & $\mathrm{F}_{1}$ & $\mathrm{M}$ & $\mathrm{F}_{1}$ \\
\hline \multirow{3}{*}{ Controls } & $\mathrm{NC}$ & $0.2 \pm 0.44$ & $0.2 \pm 0.44$ & $0.6 \pm 0.54$ & $0.2 \pm 0.44$ \\
& $\mathrm{CS}$ & $0.6 \pm 0.54$ & 0 & $0.2 \pm 0.44$ \\
& MMS & $21.2 \pm 7.08^{* 1}$ & $4.6 \pm 2.07^{* 1}$ & $20.6 \pm 5.12^{* 1}$ & $4.6 \pm 0.89^{* 1}$ \\
Raw & TRIF & $12.2 \pm 3.42^{* 1}$ & $2.6 \pm 1.14^{*}$ & $3.6 \pm 0.89^{* 1}$ & $2.6 \pm 0.89^{* 1}$ \\
Combination & B & $0.14 \pm 0.14$ & $0.05 \pm 0.04$ & NA & NA \\
\hline
\end{tabular}

NC: negative control; CS: control soil; MMS: positive control; TRIF: positive control; B: raw biosolid sample; SB: soil + biosolid. $t_{0}$ : time of mixing and $t_{30}$ : after 30 days of exposure to the diplopods.

* Statistically significant values when compared to the negative control, by Mann-Whitney test, $P<0.05$.

${ }^{1}$ Statistically significant values when compared to the control soil, by Mann-Whitney test, $P<0.01$.

${ }^{2}$ Statistically significant values when compared to the same treatments at 0 and 30 days.

NA: not available.

(Table 4) and a decrease for these values was observed after 30 days of exposure to diplopods.

\section{Discussion}

Researches about sewage sludge disposal in soil are focused on its effects on soil fertility, plant development, and contamination by heavy metals and organic compounds [24]. However, few studies have been conducted to evaluate the toxic, genotoxic, and mutagenic potentials of the sewage sludge disposal on exposed plants and animals.

Chemical analysis of biosolid sample showed the presence of trace elements. According to the literature, these elements tend to induce genotoxic and/or mutagenic effects on plants $[25,26]$ and tend to concentrate in the terrestrial invertebrates tissues because their rate of absorption frequently surpasses their rate of elimination [27].

Several authors have used higher plants to diagnose and monitor the action of chemicals and environmental pollution. Among these, Allium cepa (onion) has been used in determination of cytotoxic, genotoxic, and mutagenic effects of substances $[15,28]$ and complex environmental samples [29-36].

In this study, A. cepa assays were carried out to assess abnormalities in dividing cells and to estimate the potential of B and SB samples to induct chromosome aberrations. The mitotic index of B was statistically significant compared to control soil. In our study, the mitosis stimulation observed in $\mathrm{B}$ and $\mathrm{SB}$ treatments may be due to the phosphorus and nitrogen presence and abundant elements in domestic sewage $[37,38]$.

Chromosomal aberrations are recognized as important consequences of the genotoxic environmental chemicals actions [39], to which many organisms, including humans, are exposed. Epidemiological studies have linked high chromosomal aberrations frequencies at significant cancer developing risk [40]. For this reason, numerous biological tests for chromosomal aberrations evaluation have been developed, in order to ensure the environmental quality $[15,31]$.
The most common aberrations observed in this study were metaphase with chromosomal adherence, polyploidy anaphase, and anaphase with chromosomal bridge and nuclear bud. According to the literature, all aberrations may be caused by the action of some trace elements/metals. Some metals are potentially genotoxic/mutagenic and are strongly related to environmental pollution. Several studies with plants have shown that the genotoxic effects of metals can cause changes in chromosome structure, chromosome number, and also the disturbances in the mitotic apparatus $[25,26]$; they have the ability to inhibit mitotic spindle formation, leading to an abnormal chromosomes distribution and polyploidy [25, 41-43].

In this study was observed the presence of some elements such as barium, lead, copper, chromium, mercury, molybdenum, nickel, and zinc. Although their concentrations are within the standards established by CONAMA [14], according to De Godoy and Fontanetti [44], these standards do not take into account aspects such as the possible interaction of toxic metals and plants, as well as the lack of information regarding the influence of sludge on the soil fauna, including animals that promote humification, aeration, and enrichment of the same.

Like earthworms and collembola $[8,12,45,46]$, the diplopods are considered excellent test organisms for studying the organic amendment effects in the soil ecosystem due to their direct exposure and their sensibility to pollutants; therefore, the diplopods have been used as bioindicators of soil pollution and ecotoxicological assessment $[27,44,47$, 48 .

The stimulation of soil biota revealed in some field studies using agronomic dosage of biosolids [49] is probably linked to the soil fertility enhancement, especially due to the contribution of the organic matter. However, in some laboratory investigations, the biosolid and sewage sludge application has caused inhibitory effects [50] and tissue damage on soil invertebrates [44, 47, 48].

Morphological changes can be employed in investigations of chemicals toxicity and in monitoring of acute and chronic effects, in impacted environments [51]. Analyses 
involving morphology and histology of tissues in invertebrates have been widely used to identify different damage types caused by harmful substances to animals [52-55].

Preliminary histological analysis of the midgut of diplopods, exposed for 7 and 30 days to the SB sample, according to sewage sludge disposal for Brazilian law may help clarify the mechanisms used by animals in an attempt to detoxify the contaminants present in the biosolid when applied to the soil. It is inferred that the high rate of epithelium renewal of the midgut of these animals may be to maintain the integrity of the organ and an attempt by the body to compensate the damage suffered after the ingestion of contaminated soil [27]. Similar results were obtained by other authors in response to acute diplopods exposure to industrial soil contaminated with polycyclic aromatic hydrocarbons [27] and sewage sludge samples from different sewage treatment plants $[47,48]$.

Tissue changes related to defense and detoxification may be reversible, being present only as a result of an altered metabolic status of the organism [56]. In invertebrates, the intracellular accumulation of potentially toxic compounds in insoluble forms and in physiologically inactive ones is an efficient mechanism for detoxification of these elements $[27,57]$. In diplopods, the midgut and the hepatic cells work actively in this process $[47,57]$.

The biotransformation of toxic compounds requires the consumption of energy reserves [27]. In the present study, after 7 days of exposure, the reduction of the volume of hepatic cells of the animals exposed to SB sample could be due to the large energy demand for detoxification of the toxic compounds found in the soil. However, after 30 days of exposure, a decrease in the aggression intensity in hepatic cells of the diplopods' midgut was observed, probably due to SB sample stabilization.

At the same time, there was a reduction of SB genotoxicity in onion seeds exposed to this sample. It is inferred that the genotoxicity reduction was obtained again due to SB sample stabilization for bioprocessing of this by diplopods and subsequent immobilization of trace elements. However, under field conditions, the animals would be chronically exposed to this residue, given the frequent application of this. In this sense, it is indispensable to develop studies that evaluate the subchronic exposure effects in an attempt to measure whether responses are sufficient to maintain the organ integrity and/or if will elapse in more severe cellular/tissue damage.

\section{Conclusion}

There is evidence that biosolids use will lead to increased soil fertility and trace elements levels; therefore, the environmental significance of such increases needs to be examined.

The results of this study reinforce the need for more research to evaluate the biological effects of waste to be discharged into the environment in different ecosystems compartments, as well as different levels of biological organization, even when toxic agents are present at low concentrations, since the sample studied in accordance with Brazilian standards for sewage sludge disposal has shown toxic and genotoxic potential to onion seeds and terrestrial invertebrates.

In this sense, studies that evaluate the subchronic exposure effects in an attempt to measure how this provision can be harmful or not to the environment compartments and receptor organisms are necessary.

\section{Acknowledgments}

The authors would like to thank CNPq and FAPESPFundação de Amparo à Pesquisa do Estado de São Paulo (process number 2009/50578-3) for financial support, Américo Sampaio from SABESP-Basic Sanitation Company of the State of São Paulo, for authorizing the collection of biosolids, Dr. Paula Suares Rocha, for assistance in English language version, and Janaína Pedro-Escher, Guilherme T. Maziviero, and Juliano L. P. de Figueiredo for assistance during sampling of biosolids and experimental setup.

\section{References}

[1] R. P. Singh and M. Agrawal, "Potential benefits and risks of land application of sewage sludge," Waste Management, vol. 28, no. 2, pp. 347-358, 2008.

[2] W. Bettiol and O. A. Camargo, "A disposição de lodo de esgoto em solo agrícola," in Lodo de Esgoto: Impactos Ambientais na Agricultura, W. Bettiol and O. A. Camargo, Eds., pp. 25-36, Embrapa Meio Ambiente, Jaguariúna, Brazil, 2006.

[3] R. J. Haynes, G. Murtaza, and R. Naidu, "Chapter 4 inorganic and organic constituents and contaminants of biosolids. Implications for land application," Advances in Agronomy, vol. 104, pp. 165-267, 2009.

[4] C. Bertelli, Efeitos da disposição de lodos de curtume no solo e na planta [Ph.D. thesis], Universidade Estadual Paulista, São Paulo, Brazil, 2011.

[5] M. R. Lambais and J. B. Do Carmo, "Impacts ofbiosolids amendments on themicrobiota of tropical soils," Revista Brasileira de Ciencia do Solo, vol. 32, no. 3, pp. 1129-1138, 2008.

[6] Q. Y. Cai, C. H. Mo, Q. T. Wu, Q. Y. Zeng, A. Katsoyiannis, and J. F. Férard, "Bioremediation of polycyclic aromatic hydrocarbons (PAHs)-contaminated sewage sludge by different composting processes," Journal of Hazardous Materials, vol. 142, no. 1-2, pp. 535-542, 2007.

[7] W. J. Melo, M. O. Marques, and V. P. Melo, "O uso agrícola do biossólido e as propriedades do solo," in Biossólidos na agricultura, M. T. Tsutiya, J. B. Comparini, P. A. Sobrinho et al., Eds., pp. 289-363, São Paulo, Brazil, 2001.

[8] T. Natal-Da-Luz, S. Tidona, B. Jesus, P. V. Morais, and J. P. Sousa, "The use of sewage sludge as soil amendment-the need for an ecotoxicological evaluation," Journal of Soils and Sediments, vol. 9, no. 3, pp. 246-260, 2009.

[9] C. E. Martínez and M. B. Mcbride, "Copper phytotoxicity in a contaminated soil: remediation tests with adsorptive materials," Environmental Science and Technology, vol. 34, no. 20, pp. 4386-4391, 2000.

[10] M. Khan and J. Scullion, "Effect of soil on microbial responses to metal contamination," Environmental Pollution, vol. 110, no. 1, pp. 115-125, 2000.

[11] D. J. Spurgeon and S. P. Hopkin, "Comparisons of metal accumulation and excretion kinetics in earthworms (Eisenia fetida) exposed to contaminated field and laboratory soils," Applied Soil Ecology, vol. 11, no. 2-3, pp. 227-243, 1999. 
[12] N. Artuso, T. F. Kenedy, J. Connery, J. Grant, and O. Schmidt, "Effects of biosolids at varying rates on earthworms (Eisenia fetida) and springtails (Folsomia candida)," Applied and Environmental Soil Science, vol. 2011, Article ID 519485, 10 pages, 2011.

[13] Instituto Brasileiro de Geografia e Estatística, http://www.ibge .gov.br/home/estatistica/populacao/censo2010/tabelas_pdf/ total_populacao_sao_paulo.pdf, 2010.

[14] Conselho Nacional do Meio Ambiente, "Define critérios e procedimentos para o uso de lodos de esgoto gerados em estações de tratamento de esgoto sanitário e seus produtos derivados," Resolução number 375, Diário Oficial da União, DF, Brazil, 2006.

[15] T. C. C. Fernandes, D. E. C. Mazzeo, and M. A. Marin-Morales, "Mechanism of micronuclei formation in polyploidizated cells of Allium cepa exposed to trifluralin herbicide," Pesticide Biochemistry and Physiology, vol. 88, no. 3, pp. 252-259, 2007.

[16] J. Rank and M. H. Nielsen, "Allium cepa anaphase-telophase root tip chromosome aberration assay on N-methyl-N-nitrosourea, maleic hydrazide, sodium azide, and ethyl methanesulfonate," Mutation Research, vol. 390, no. 1-2, pp. 121-127, 1997.

[17] M. L. S. Mello and B. C. Vidal, “A reação de Feulgen," Ciência e Cultura, vol. 30, pp. 665-676, 1978.

[18] Z. Zakeri and R. A. Lockshin, "Cell death during development," Journal of Immunological Methods, vol. 265, no. 1-2, pp. 3-20, 2002.

[19] I. M. Cristea and M. D. Esposti, "Membrane lipids and cell death: an overview," Chemistry and Physics of Lipids, vol. 129, no. 2, pp. 133-160, 2004.

[20] D. M. Leme and M. A. Marin-Morales, "Allium cepa test in environmental monitoring: a review on its application," Mutation Research, vol. 682, no. 1, pp. 71-81, 2009.

[21] T. H. Ma and Z. Xu, "Validation of a new protocol of the Allium micronucleus test for clastogens," Environmental Mutagenesis, vol. 8, no. 6, pp. 65-66, 1986.

[22] Companhia Ambiental do Estado de São Paulo, "Valores orientadores para solos e águas subterrâneas no Estado de São Paulo," Norma number 195/2005-E, São Paulo, Brazil, 2005.

[23] E. R. Fantazzini, C. S. Fontanetti, and M. I. Camargo-Mathias, "Midgut of the millipede, "Rhinocricus padbergi" Verhoeff, 1938 (Diplopoda: Spirobolida): histology and histochemistry," Arthropoda Selecta, vol. 11, pp. 135-142, 2002.

[24] W. Bettiol and R. Ghini, "Impacts of sewage sludge in tropical soil: a case study in Brazil," Applied and Environmental Soil Science, vol. 2011, Article ID 212807, 11 pages, 2011.

[25] G. Fisjekö, "Nucleolar dissolution induced by aluminium in root cells of Allium," Physiologia Plantarum, vol. 59, pp. 508$511,1983$.

[26] S. Minissi and E. Lombi, "Heavy metal content and mutagenic activity, evaluated by Vicia faba micronucleus test, of Tiber river sediments," Mutation Research, vol. 393, no. 1-2, pp. 1721, 1997.

[27] T. D. S. Souza and C. S. Fontanetti, "Morphological biomarkers in the Rhinocricus padbergi midgut exposed to contaminated soil," Ecotoxicology and Environmental Safety, vol. 74, no. 1, pp. 10-18, 2011.

[28] W. F. Grant, "The present status of higher plant bioassays for the detection of environmental mutagens," Mutation Research, vol. 310, no. 2, pp. 175-185, 1994.

[29] S. Cotelle, J. F. Masfaraud, and J. F. Férard, "Assessment of the genotoxicity of contaminated soil with the Allium/Viciamicronucleus and the Tradescantia-micronucleus assays," Mutation Research, vol. 426, no. 2, pp. 167-171, 1999.
[30] I. S. Grover and S. Kaur, "Genotoxicity of wastewater samples from sewage and industrial effluent detected by the Allium root anaphase aberration and micronucleus assays," Mutation Research, vol. 426, no. 2, pp. 183-188, 1999.

[31] S. T. Matsumoto and M. A. Marin-Morales, "Mutagenic potential evaluation of the water of a river that receives tannery effluent using the Allium cepa test system," Cytologia, vol. 69, no. 4, pp. 399-408, 2004.

[32] C. K. Grisolia, A. B. B. de Oliveira, H. Bonfim, and M. D. Klautau-Guimarães, "Genotoxicity evaluation of domestic sewage in a municipal wastewater treatment plant," Genetics and Molecular Biology, vol. 28, no. 2, pp. 334-338, 2005.

[33] L. C. Monte Egito, M. das Graças Medeiros, S. R. B. de Medeiros, and L. F. Agnez-Lima, "Cytotoxic and genotoxic potential of surface water from the Pitimbu river, northeastern/RN Brazil," Genetics and Molecular Biology, vol. 30, no. 2, pp. 435-441, 2007.

[34] R. Caritá and M. A. Marin-Morales, "Induction of chromosome aberrations in the Allium cepa test system caused by the exposure of seeds to industrial effluents contaminated with azo dyes," Chemosphere, vol. 72, no. 5, pp. 722-725, 2008.

[35] D. M. Leme and M. A. Marin-Morales, "Chromosome aberration and micronucleus frequencies in Allium cepa cells exposed to petroleum polluted water-a case study," Mutation Research, vol. 650, no. 1, pp. 80-86, 2008.

[36] T. S. Souza, F. A. Hencklein, D. F. Angelis, R. A. Gonçalves, and C. S. Fontanetti, "The Allium cepa bioassay to evaluate landfarming soil, before and after the addition of rice hulls to accelerate organic pollutants biodegradation," Ecotoxicology and Environmental Safety, vol. 72, no. 5, pp. 1363-1368, 2009.

[37] B. Wang, "Cultural eutrophication in the Changjiang (Yangtze River) plume: history and perspective," Estuarine, Coastal and Shelf Science, vol. 69, no. 3-4, pp. 471-477, 2006.

[38] C. Quiblier, C. Leboulanger, S. Sané, and P. Dufour, "Phytoplankton growth control and risk of cyanobacterial blooms in the lower Senegal River delta region," Water Research, vol. 42, no. 4-5, pp. 1023-1034, 2008.

[39] A. T. Natarajan, "Chromosome aberrations: past, present and future," Mutation Research, vol. 504, no. 1-2, pp. 3-16, 2002.

[40] M. G. Obe, P. Pfeiffer, J. R. K. Savage et al., "Chromosomal aberrations: formation, identification and distribution," Mutation Research, vol. 504, no. 1-2, pp. 17-36, 2002.

[41] S. De Flora, C. Bennicelli, and M. Bagnasco, "Genotoxicity of mercury compounds. A review," Mutation Research, vol. 317, no. 1, pp. 57-79, 1994.

[42] G. Voutsinas, F. E. Zarani, and A. Kappas, "The effect of environmental aneuploidy-inducing agents on the microtubule architecture of mitotic meristematic root cells in Hordeum vulgare," Cell Biology International, vol. 21, no. 7, pp. 411-418, 1997.

[43] P. C. S. Cardoso, P. L. Lima, M. O. Bahia, M. I. M. Amorim, R. R. Burbano, and R. A. F. Farias, "Efeitos biológicos do mercúrio e seus derivados em seres humanos—uma revisão bibliográfica," Belém: Universidade Federal do Pará, http:// www.facome.uqam.ca/pdf/cardoso_2002.PDF.

[44] J. A. P. De Godoy and C. S. Fontanetti, "Diplopods as bioindicators of soils: analysis of midgut of individuals maintained in substract containing sewage sludge," Water, Air, and Soil Pollution, vol. 210, no. 1-4, pp. 389-398, 2010.

[45] P. Alvarenga, P. Palma, A. P. Gonçalves et al., "Evaluation of chemical and ecotoxicological characteristics of biodegradable organic residues for application to agricultural land," Environment International, vol. 33, no. 4, pp. 505-513, 2007. 
[46] R. Moreira, J. P. Sousa, and C. Canhoto, "Biological testing of a digested sewage sludge and derived composts," Bioresource Technology, vol. 99, no. 17, pp. 8382-8389, 2008.

[47] L. R. Nogarol and C. S. Fontanetti, "Acute and subchronic exposure of diplopods to substrate containing sewage mud: tissular responses of the midgut," Micron, vol. 41, no. 3, pp. 239-246, 2010.

[48] D. G. Perez and C. S. Fontanetti, "Assessment of the toxic Potential of sewage sludge in the Midgut of the Diplopod Rhinocricus padbergi," Water, Air and Soil Pollution, vol. 218, no. 1-4, pp. 1-8, 2010.

[49] L. J. Cole, D. I. McCracken, G. N. Foster, and M. N. Aitken, "Using Collembola to assess the risks of applying metalrich sewage sludge to agricultural land in Western Scotland," Agriculture, Ecosystems and Environment, vol. 83, no. 1-2, pp. 177-189, 2001.

[50] P. Andrés and X. Domene, "Ecotoxicological and fertilizing effects of dewatered, composted and dry sewage sludge on soil mesofauna: a TME experiment," Ecotoxicology, vol. 14, no. 5, pp. 545-557, 2005.

[51] T. R. Meyers and J. D. Hendricks, "Histopathology," in Fundamental of Aquatic Toxicology: Methods and Applications, G. M. Rand and S. R. Petrocelli, Eds., pp. 283-331, Washington, DC, USA, 1985.

[52] H. R. Köhler and R. Triebskorn, "Assessment of the cytotoxic impact of heavy metals on soil invertebrates using a protocol integrating qualitative and quantitative components," Biomarkers, vol. 3, no. 2, pp. 109-127, 1998.

[53] R. Triebskorn, H. R. Köhler, T. Zanh et al., "Invertebrate cells as targets for hazardous substances," Zeitschfirt fuer Angewandte Zoologie, vol. 78, pp. 277-287, 1991.

[54] R. A. Triebskorn, I. F. Henderson, and A. P. Martin, "Detection of iron in tissues from slugs (Deroceras reticulatum Muller) after ingestion of iron chelates, by means of energy-filtering transmission electron microscopy (EFTEM)," Pesticide Science, vol. 55, no. 1, pp. 55-61, 1999.

[55] C. S. Fontanetti, C. A. Christofoletti, T. G. Pinheiro, T. S. Souza, and J. Pedro-Escher, "Microscopy as a tool in toxicological evaluations," in Microscopy: Science, Technology, Applications and Education, A. Méndez-Vilas and J. Diaz, Eds., pp. 1001-1007, Formatex Research Center, Badajoz, Spain, 2010.

[56] V. Nero, A. Farwell, A. Lister et al., "Gill and liver histopathological changes in yellow perch (Perca flavescens) and goldfish (Carassius auratus) exposed to oil sands process-affected water," Ecotoxicology and Environmental Safety, vol. 63, no. 3, pp. 365-377, 2006.

[57] H. R. Köhler, "Localization of metals in cells of saprophagous soil arthropods (Isopoda, Diplopoda, Collembola)," Microscopy Research and Technique, vol. 56, no. 5, pp. 393-401, 2002. 

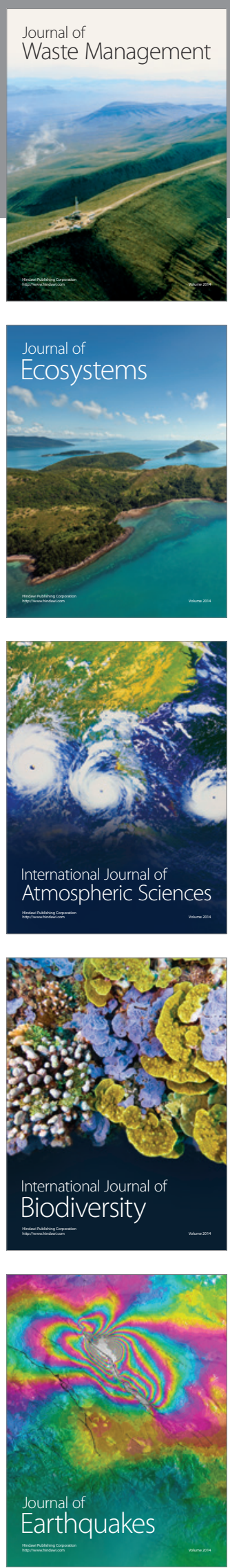
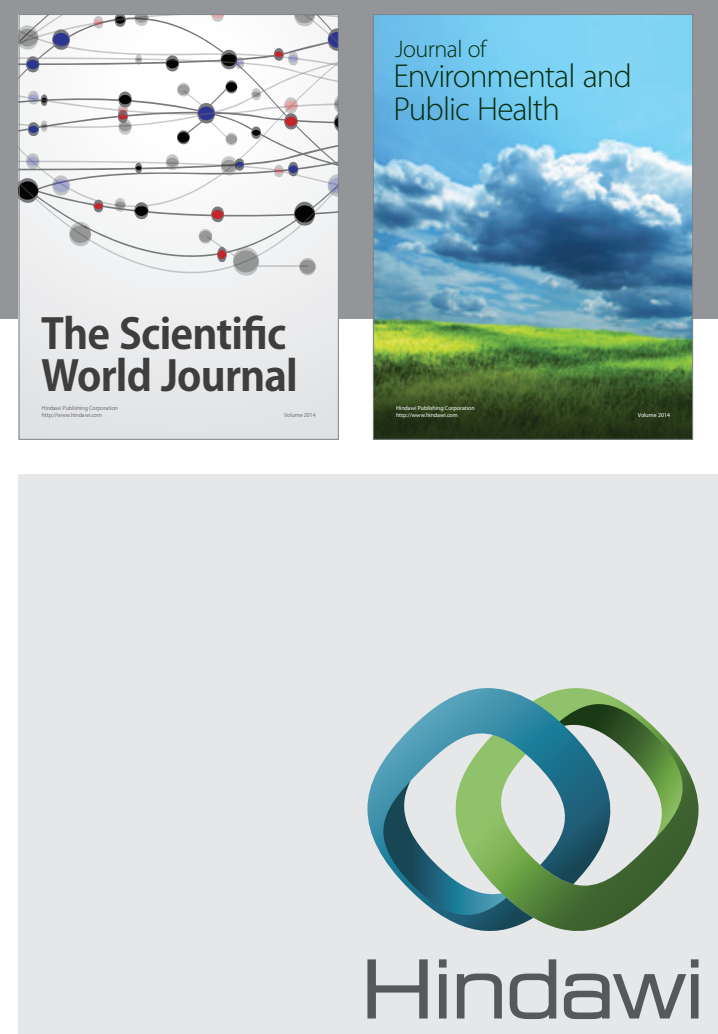

Submit your manuscripts at

http://www.hindawi.com
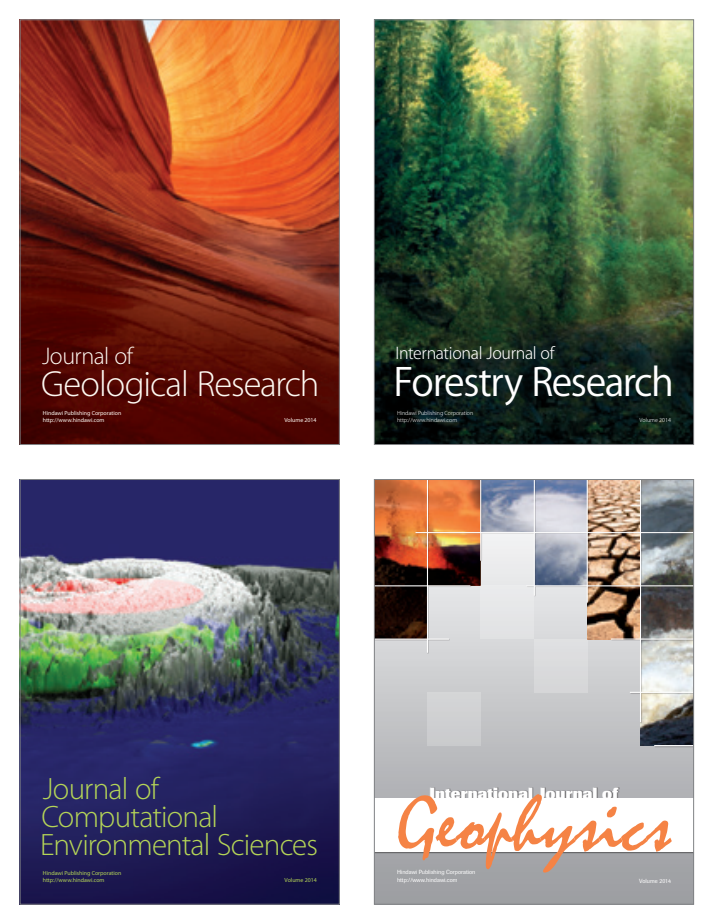
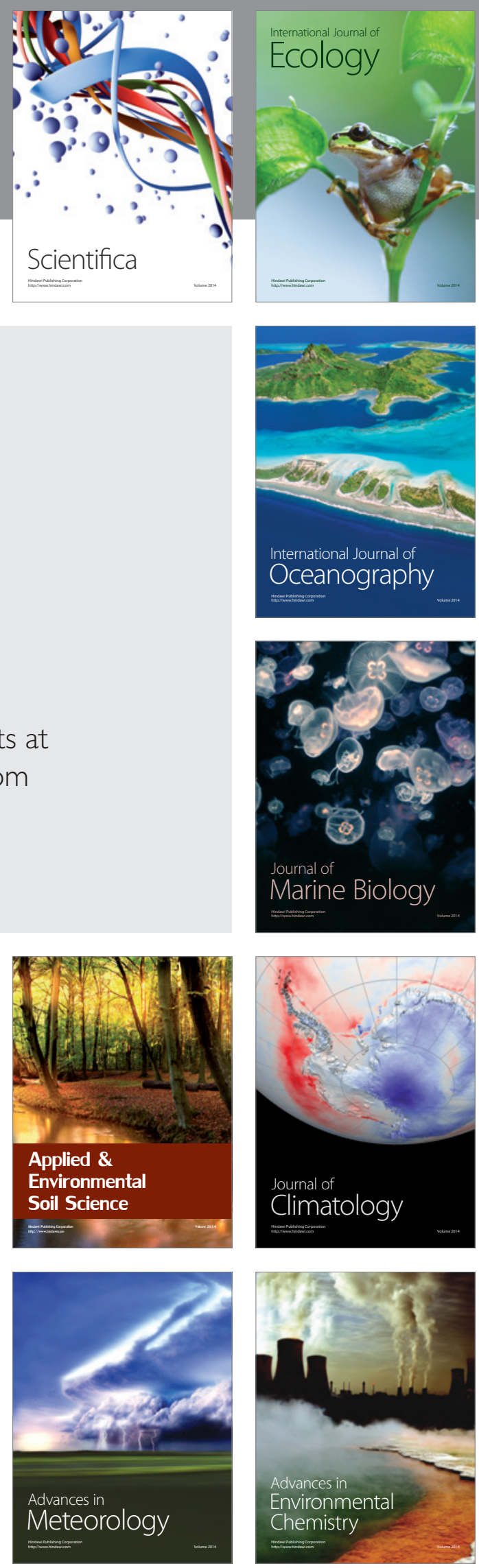